\title{
PROBLEM LEGALIZACJI NARKOTYKÓW MIĘKKICH W POLSCE NA TLE REGULACJI PRAWNYCH PRZYJĘTYCH W REPUBLICE CZESKIEJ ORAZ W KRÓLESTWIE NIDERLANDÓW
}

\begin{abstract}
Streszczenie. Celem niniejszej publikacji jest przybliżenie unormowań prawnych odnoszących się do problematyki legalizacji oraz dostępności narkotyków miękkich w Polsce. W oparciu o regulacje prawa międzynarodowego, a także najważniejsze akty prawa wewnątrzwspólnotowego wskazuje się na zasadnicze przyczyny, dla których depenalizacja zachowań polegających na posiadaniu bądź też wytwarzaniu tzw. soft drugs nie jest obecnie możliwa. Zestawienie przepisów karnych polskiej ustawy narkotykowej pozwala wytyczać pożądane kierunki zmian w polskim modelu prohibicyjnym. W tym kontekście autor prezentuje podstawowe założenia polityk antynarkotykowych przyjętych w Republice Czeskiej oraz w Królestwie Niderlandów, jako państw o mniej restrykcyjnym (radykalnym) podejściu do kwestii posiadania narkotyków. Podjęte rozważania pozwalają ostatecznie na sformułowanie odpowiedzi na pytanie: Czy zasadne jest zalegalizowanie chociażby tzw. „narkotyków miękkich”, czy też należy pozostawić obowiązujące unormowania prawne bez zmian, karząc zawsze i za każdy przejaw posiadania narkotyków i to bez względu na ich rodzaj?
\end{abstract}

Słowa kluczowe: narkotyki, kryminalizacja, dekryminalizacja, posiadanie narkotyków, narkotyki miękkie, legalizacja, prohibicja.

\section{WSTĘP}

Legalizacja narkotyków miękkich w Polsce jest od dawna przedmiotem licznych debat zarówno ze strony doktryny prawa karnego, jak również w kręgu różnorakich środowisk politycznych. Argumenty przemawiające za powszechną dostępnością oraz legalizacją takich używek jak chociażby marihuana czy haszysz przeplatają się z bardziej konserwatywnymi poglądami etyków, przedstawicieli organów ścigania, jak również osób zajmujących się na co dzień profilaktyką oraz terapią uzależnień. Pomimo że narkotyki miękkie, stojąc w opozycji do tzw. narkotyków twardych jak amfetamina czy też heroina, są bez wątpienia jedną z przyczyn wzrostu uzależnień, zwłaszcza w kręgu młodzieży szkolnej, coraz częściej

\footnotetext{
* Uniwersytet łódzki, Wydział Prawa i Administracji, Katedra Prawa Karnego, fieduk@wp.p1/.
} 
pojawiają się głosy na temat ich pozytywnego wpływu na leczenie niektórych ciężkich chorób autoimmunologicznych, chorób układu nerwowego, a nawet chorób nowotworowych ${ }^{1}$.

Należy stwierdzić, że większość używek, które pojawiły się na przestrzeni wieków, jest świadomym i celowym wytworem działalności człowieka. Heroina jako finalny produkt badań niemieckiego farmaceuty Heinricha Dresslera, od 1898 roku sprzedawana była w aptekach przez koncern chemiczny Bayer, służąc jako preparat skuteczny w leczeniu kaszlu². Dopiero liczne doniesienia o niekorzystnym i silnie uzależniającym wpływie wymienionej używki na organizm ludzki doprowadziły do jej szybkiego wycofania z rynku.

Podobnie przedstawia się historia innych narkotyków, zarówno tych syntetycznych, jak i tych naturalnego pochodzenia, które pierwotnie wykorzystywane były w innych celach niż do wywołania efektu odurzenia. Amfetamina, a ściślej mówiąc siarczan amfetaminy, zsyntetyzowana po raz pierwszy w 1887 roku w USA pod nazwą handlową benzydyna, początkowo wykorzystywana była jako preparat stosowany do leczenia między innymi astmy oskrzelowej, czy też narkolepsji ${ }^{3}$. Popularny na przełomie XX i XXI wieku halucynogen o nazwie LSD, czyli dietyloamid kwasu D-lizergowego, zsyntetyzowany w 1938 roku przez chemika Alberta Hofmanna, służyć miał jako lek działający rozkurczowo na macicę i ułatwiający w ten sposób poród ${ }^{4}$. Natomiast kokaina, wyekstrahowana w 1860 roku przez Alberta Niemanna, znalazła zastosowanie w okulistyce oraz stomatologii. Warto zauważyć, że aż do 1903 roku opakowanie popularnego napoju Coca-Cola zawierało aż $60 \mathrm{mg}$ czystej kokainy ${ }^{5}$.

Jeżeli chodzi o tzw. „narkotyki miękkie”, to należy stwierdzić, iż pierwsze wzmianki na temat ich pojawienia się w Europie sięgają starożytności. W tym czasie w zachodnim rejonie Morza Śródziemnego prowadzono uprawy maku. Uprawy te, datowane na VI tysiąclecie p.n.e., z czasem rozprzestrzeniły się na resztę obszaru Europy oraz na tereny dzisiejszej Azji Mniejszej. Z maku wytwarzane jest opium, które służy osiąganiu odmiennych stanów świadomości, bądź też wykorzystywane jest w celu uśmierzania bólu. Woreczki zawierające ten narkotyk odkrywane są w grobach na stanowiskach archeologicznych znajdujących się w południowej Hiszpanii w okolicach miejscowości Albunol (stanowisko archeologiczne datowane na 4200 r. p.n.e.). Badania archeologiczne, a także wzmianki zawarte w starożytnych rękopisach pozwalają stwierdzić, że również konopie indyjskie oraz haszysz stanowiły niezwykle popularne używki ówczesnych mieszkańców Europy. Świadczą o tym chociażby odkrycia z Rumunii, gdzie odnalezio-

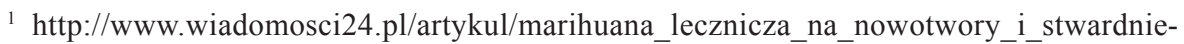
nie_rozsiane_bedzie_rewolucja_w_polskiej_medycynie_297737.html [dostęp 25.07.2015].

2 http://opioids.com/heroin/heroinhistory.html [dostęp 25.07.2015].

${ }^{3} \mathrm{http}: / /$ www.cesar.umd.edu/cesar/drugs/amphetamines.pdf [dostęp 25.07.2015].

${ }^{4} \mathrm{http} / / /$ narkotyki.org/narkotyki/lsd/ [dostęp 25.07.2015].

${ }^{5}$ http://narkotyki.org/narkotyki/kokaina/ [dostęp 25.07.2015]. 
no palenisko datowane na III tysiąclecie przed naszą erą, w którym to archeolodzy odnaleźli resztki konopi indyjskich. Przypadki zażywania haszyszu odnotowano również w $\mathrm{V}$ wieku p.n.e. wśród Scytów (koczownicze ludy Irańskie) ${ }^{6}$.

Reasumując, stwierdzić można, że narkotyki już dawno pojawiły się w wielu społecznościach europejskich, a co za tym idzie, nie są czynnikiem obcym również dla polskiej kultury.

Jednym z wielu argumentów na poparcie tezy o wielowiekowym koegzystowaniu różnorakich używek w świadomości Polaków może być cytat z powieści E. Orzeszkowej Nad Niemnem (z epoki pozytywizmu), gdzie jeden z bohaterów wypowiadając się na temat swojego uzależnienia od morfiny, stwierdza:

„Z początku zadawano mi znaczne dozy narkotyku tego dla zmniejszenia bólów, a potem przywykłem. Jedyne to już dla mnie wyjście, przez które uciekam od ciężkiej nudy, od upadku sił i może jeszcze od... od czegoś podobnego do rozpaczy!" (Orzeszkowa 1984, 7).

Przytoczony cytat potwierdza, że narkotyki pojawiły się na ziemiach polskich dużo wcześniej niż można by przypuszczać, a wzrastająca tendencja do ich zażywania nie jest trendem ostatnich lat. Wytwarzanie narkotyków miękkich, takich jak chociażby marihuana, nie jest procesem trudnym i nie wymaga specjalistycznego sprzętu ani zawiłych procedur chemicznych. $Z$ uwagi na powyższe proceder ten przybiera coraz większe rozmiary w skali globalnej. Należy stwierdzić, że rosnące zapotrzebowanie na substancje psychoaktywne znacząco generuje ich podaż. W rezultacie tego procesu narkotyki stają się coraz bardziej popularne, zastępując inne tradycyjne używki - takie jak chociażby alkohol.

Czemu zatem istnieje tak poważny rozdźwięk między postulatami zalegalizowania narkotyków miękkich a bardziej radykalnymi stanowiskami przeciwników tejże legalizacji?

Jeżeli przyjrzeć się raportom dotyczącym skali uzależnień, to daje się zauważyć, że bez wątpienia dużo większym problemem w skali globalnej, jak i lokalnej, jest uzależnienie od alkoholu. Dostępne dane statystyczne wskazują, że w Polsce żyje obecnie około 800 tysięcy ludzi uzależnionych od tej używki, nie mówiąc już o liczbie osób, które szkodliwie nadużywają alkoholu? . Jeżeli chodzi o liczbę osób uzależnionych od marihuany, to jest ona trudna do oszacowania z uwagi na nielegalny charakter tej substancji. W każdym bądź razie szacuje się, że około $8 \%$ populacji dorosłych Polaków w pewnym momencie swojego życia paliło ten narkotyk ${ }^{8}$.

Koronnym argumentem dla przeciwników legalizacji narkotyków miękkich jest teza, że każdy czynny narkoman zaczynał kiedyś od palenia tzw. „trawki”, a następnie, w efekcie stopniowego popadania w nałóg, sięgał po coraz silniejsze

\footnotetext{
${ }^{6} \mathrm{http}: / /$ www.parentscontreladrogue.com/marihuana.htm [dostęp 25.07.2015].

${ }^{7} \mathrm{http}: / /$ www.parpa.pl/index.php/analizy-badania-raporty/statystyki [dostęp 27.07.2015].

${ }^{8}$ http://www.menshealth.pl/zdrowie/Marihuana-co-w-trawie-piszczy,3638,1 [dostęp 27.07.2015].
} 
narkotyki. Jednakże przytoczone stwierdzenie wydaje się być nie do końca trafione, gdyż podobna teza wygłoszona w stosunku do osób nadużywających alkoholu - np. w postaci piwa, już na wstępie podlegałaby odrzuceniu. Oznacza to, że nie każdy kto lubi pić piwo, stanie się nagle zwolennikiem silniejszego alkoholu, jakim jest chociażby wódka. Podobnie wydaje się być w przypadku marihuany, jednakże $\mathrm{z}$ uwagi na penalizację posiadania tej używki w wielu systemach prawnych uzyskanie miarodajnych danych statystycznych jest $\mathrm{w}$ tej chwili znacznie utrudnione. Należy pamiętać, że uzależnienie to proces długotrwały, na który duży wpływ wywierają tak cechy psychofizyczne określonej osoby, jak również pewnego rodzaju predyspozycje genetyczne. Zatem większa dostępność do narkotyków miękkich sama w sobie nie przesądza jeszcze o fakcie wzrostu liczby uzależnień.

Należy pamiętać, że limitowanie dostępu do określonych używek napędza tzw. „szarą strefę" lub może wygenerować wzrost dostępności do alternatywnych używek, jakimi są chociażby „dopalacze”. Zjawisko to wydaje się być niezwykle niepokojące.

\section{REGULACJE PRAWA MIĘDZYNARODOWEGO JAKO BARIERA DLA LEGALIZACJI NARKOTYKÓW MIĘKKICH W PAŃSTWACH UNII EUROPEJSKIEJ}

Pomimo zwiększającej się dostępności do różnorakich używek, ewentualna legalizacja narkotyków miękkich ciągle nastręcza szereg problemów natury etycznej, jak i normatywnej. Z uwagi na brzmienie przepisów prawnych wiążących Rzeczpospolitą Polską (jako członka Unii Europejskiej) prowadzenie debaty na temat legalizacji tychże narkotyków wydaje się zatem być bezcelowe. W obecnym stanie prawnym, co warto dobitnie podkreślić, nie ma możliwości legalizacji jakichkolwiek narkotyków na terenie Rzeczypospolitej Polskiej. Jest to wynikiem ratyfikowania przez Rzeczpospolitą Polską Konwencji Narodów Zjednoczonych o zwalczaniu nielegalnego obrotu środkami odurzającymi i substancjami psychotropowymi (Konwencja Narodów Zjednoczonych 1988).Wskazany akt prawny poprzedzony został dwiema ważnymi regulacjami prawa międzynarodowego, $\mathrm{tj}$.:

- Jednolitą konwencją o środkach odurzających z 1961 roku (Jednolita Konwencja... 1961) oraz

- Konwencją o substancjach psychotropowych z 1971 roku (Konwencja o substancjach psychotropowych...1971).

Na mocy art. 36 ust. 1 pkt. a Jednolitej konwencji z 1961 roku, poszczególne państwa-sygnatariusze zobowiązują się:

„Aby uprawa, zbiór, wyrób, sporządzanie wyciągów, przetwarzanie, posiadanie, oferowanie, oferowanie do sprzedaży, rozpowszechnianie, kupno, sprzedaż, 
dostarczanie na jakichkolwiek warunkach, pośredniczenie, wysyłanie, przesyłanie w tranzycie, przewóz, przywóz i wywóz środków odurzających, sprzeczne z postanowieniami niniejszej konwencji, i wszelkie inne czynności, które w przekonaniu danej Strony mogą być w sprzeczności z postanowieniami niniejszej konwencji, były uznane za przestępstwa karalne, gdy popełniane są umyślnie, i aby poważne przestępstwa podlegały odpowiedniej karze, a w szczególności karze więzienia lub innej karze pozbawienia wolności”.

Kolejne przepisy cytowanego aktu prawnego przewidują penalizację różnych form popełnienia powyższych przestępstw, a także wyznaczają przesłanki ponoszenia odpowiedzialności karnej w warunkach tzw. recydywy międzynarodowej. Zasada terytorialności, odnosząca się do jurysdykcji krajowej, jest tutaj przeciwstawiana ekstradycji - mając zastosowanie jedynie w przypadku, gdy ekstradycja z przyczyn prawnych nie może zostać przeprowadzona. Analogiczne rozwiązania, jeśli chodzi o przesłanki ponoszenia odpowiedzialności karnej za pewne zachowania związane ze sferą podaży, jak również popytu na substancje psychotropowe, zawarte są natomiast w Konwencji z 1971 roku.

Analiza przepisów przywołanych aktów prawnych daje zatem podstawę do stwierdzenia, że obydwie konwencje mają na celu zaostrzenie administracyjnej kontroli nad szeroko rozumianym handlem i obrotem środkami odurzającymi oraz substancjami psychotropowymi. Kontrola ta ostatecznie zmierzać ma do wyeliminowania użycia tych substancji w celach innych niż naukowe i medyczne.

Państwa-sygnatariusze, poprzez ratyfikację Konwencji z 1961 roku oraz Konwencji z 1971 roku, zobowiązują się m.in. do:

- monitorowania produkcji i sprzedaży substancji psychotropowych, w szczególności poprzez kontrolę wydawania recept oraz prowadzenie rejestru obrotu lekami;

- odgórnego ustalania na szczeblu krajowym poziomu produkcji i konsumpcji określonych środków;

- prowadzenia badań statystycznych dotyczących m.in. poziomu zażywania środków odurzających;

- kontroli importu i eksportu określonych substancji oraz

- podjęcia działań zmierzających do ograniczenia zjawiska nielegalnego obrotu tymi substancjami poprzez podjęcie współpracy międzynarodowej.

Ukoronowaniem działań społeczności międzynarodowej w zakresie ograniczenia dostępności do substancji psychoaktywnych jest Konwencja ONZ z 1988 roku o zwalczaniu nielegalnego obrotu środkami odurzającymi i substancjami psychotropowymi. Dokument ten przewiduje najdalej idące ograniczenia $\mathrm{w}$ sferze dysponowania tego rodzaju używkami, poprzez penalizację samego faktu posiadania substancji psychoaktywnych do osobistego użytku (niezależnie od ich ilości i rodzaju). Stanowi o tym treść art. 3 ust. 2 Konwencji z 1988 roku: 
„Z zastrzeżeniem postanowień swej konstytucji i podstawowych zasad swojego systemu prawnego, każda Strona podejmie środki niezbędne do tego, aby posiadanie, nabywanie lub uprawa środków odurzających lub substancji psychotropowych dla osobistego użytku niezgodne z postanowieniami Konwencji z 1961 roku z późn. zm. lub Konwencji z 1971 roku zostało uznane, zgodnie z jego ustawodawstwem, jeżeli zostało to dokonane umyślnie, za przestępstwo podlegające karze".

Brzmienie przytoczonego powyżej przepisu wskazuje na postępującą radykalizację międzynarodowej polityki prohibicyjnej, a tym samym stanowi zasadniczą przyczynę, dla której posiadanie narkotyków jest penalizowane m.in. w ustawodawstwach polskim, czeskim czy też holenderskim.

W tym momencie należy podkreślić, że wskazane państwa, będąc członkami Unii Europejskiej, poprzez ratyfikację Konwencji z 1988 roku, stwarzają ramy prawne dla limitacji wszelkich form konsumenckiego popytu na narkotyki miękkie. Odzwierciedlenie wymogów powyższego aktu normatywnego w porządkach prawnych wymienionych państw, niewątpliwie wymusza potrzebę przeredagowania wielu przepisów ich prawa krajowego. Wskazuje się zwłaszcza na konieczność stworzenia regulacji pozwalających na skuteczne ściągnięcie korzyści majątkowej uzyskanej przez sprawcę na skutek popełnienia czynów niezgodnych z postanowieniami ratyfikowanej Konwencji. Takie podejście sprzyja ujawnianiu nielegalnych źródeł przychodu i tym samym odcina sprawców od „owoców przestępstwa" - co ma kluczowe znaczenie w ograniczeniu popytu na narkotyki. Poza tym zagadnieniem Konwencja o zwalczaniu nielegalnego obrotu środkami odurzającymi i substancjami psychotropowymi reguluje podstawowe zasady dotyczące wzajemnej współpracy międzynarodowej w obszarze zwalczania przestępczości narkotykowej między państwami będącymi stronami tej umowy. W dokumencie tym zawarte są między innymi przepisy odnoszące się do ekstradycji oraz do międzynarodowej pomocy prawnej. Regulacji poddano również procedury tzw. „dostaw niejawnych kontrolowanych”, stanowiących szczególną formę prowokacji.

W ten sposób Konwencja z 1998 roku wprowadza nowe mechanizmy oddziaływania prawnego, co ostatecznie pozwala na jeszcze skuteczniejsze ograniczenie międzynarodowej przestępczości narkotykowej. Wspomnieć należy, iż kontrola oraz nadzór nad przestrzeganiem postanowień przywołanych powyżej konwencji powierzone zostają licznym organom międzynarodowym, na czele z INCB, czyli Międzynarodowym Organem Kontroli Środków Odurzających. INCB przedkłada coroczne raporty o funkcjonowaniu globalnej polityki antynarkotykowej Radzie Gospodarczo-Społecznej ONZ 9 .

Odmienne stanowisko, jeśli chodzi o podejście do problemu narkomanii oraz towarzyszącego temu zjawisku wzrostu uzależnień, charakterystyczne jest dla unormowań prawnych przyjętych w Unii Europejskiej. Należy zauważyć, że

\footnotetext{
${ }^{9}$ http://www.unic.un.org.pl/incb/index.php [dostęp 28.07.2015].
} 
przepisy obowiązujące $\mathrm{w}$ prawie międzynarodowym stopniowo zmierzają $\mathrm{w}$ kierunku wprowadzenia modelu całkowitej prohibicji, podczas gdy podejście prawa unijnego cechuje się nieco większym liberalizmem. Najważniejszym aktem prawnym, w którym uwidacznia się postępująca radykalizacja stanowiska ONZ w walce z narkomanią, jest bez wątpienia przytaczana Konwencja z 1988 roku. Wprowadza ona m.in. zakaz posiadania do własnego użytku konsumentów jakichkolwiek narkotyków. Przyjęta regulacja stoi zatem na przeszkodzie dla wdrożenia programów opartych na tzw. ,zasadzie redukcji szkód”, obejmujących różnorakie formy leczenia substytucyjnego.

Zupełnie inne podejście prawa unijnego do tego problemu wyraża się chociażby w Zaleceniach Rady WE z dnia 18 czerwca 2003 r. (Zalecenia Rady 2003/488/WE). Punkt 6 wskazanych rekomendacji stanowi, że:

„Poszczególne kraje członkowskie powinny między innymi zapewnić dostęp zarówno do leczenia typu drug-free, jak leczenia substytucyjnego wspartego odpowiednimi dzialaniami z zakresu opieki psychospołecznej i rehabilitacji, mając na uwadze fakt, iż szeroki wachlarz metod leczniczych powinien być dostępny dla osób nadużywających narkotyków".

Akceptacja metod opartych na leczeniu substytucyjnym, jako uzupełnienie innych form terapii w leczeniu osób uzależnionych od narkotyków, pozwala przyjąć, że Unia Europejska stwarza warunki do rozwoju systemów opartych na permisji. Również Komunikat Komisji do Rady i Parlamentu Europejskiego z dnia 15 grudnia 2005 r., w ramach szeroko rozumianej polityki redukcji szkód, zachęca państwa członkowskie UE do zwiększenia dostępu do leczenia substytucyjnego (Komunikat Komisji COM/2005/0654).

Należy podkreślić, że koronnym argumentem wskazującym na wzrost znaczenia leczenia substytucyjnego w ograniczeniu popytu na wszelakie narkotyki na obszarze UE są postanowienia tzw. II Układu z Schengen z dnia 19 czerwca 1990 roku (Konwencja Wykonawcza do Układu z Schengen, 19). Wskazany dokument stanowi akt wykonawczy do Układu z Schengen z dnia 14 czerwca 1985 r., którego sygnatariuszami są Francja, ówczesne RFN, a także kraje Beneluksu (Układ z Schengen, 13). Brzmienie art. 71 ust. 1 Konwencji Wykonawczej (Schengen II) zawiera sformułowanie: „Strony powinny uczynić wszystko, co w ich mocy dla zmniejszenia popytu na narkotyki”, które wydaje się wskazywać, iż zwalczanie popytu na substancje psychoaktywne nie musi następować poprzez obligatoryjne zastosowanie sankcji karnych kierowanych względem osób posiadających narkotyki na własny użytek. Tym samym otwiera się droga do innych alternatywnych form oddziaływania pozaprawnego na rzecz ograniczenia popytu na substancje psychoaktywne. Przykładem może być tutaj chociażby wspomniane leczenie substytucyjne. Natomiast jeżeli chodzi o zwalczanie podaży na substancje psychoaktywne, to państwa-strony Układu Schengen II (zgodnie z art. 71 ust. 1 i 2 cyt. aktu) mają w tym zakresie bezwzględny obowiązek zastosowania środków oddziaływania karnego dla zniwelowania tego niekorzystnego zjawiska. 
W ten sposób Unia Europejska poprzez wprowadzenie różnorakich unormowań prawnych wyraźnie oddziela obszar podaży od obszaru popytu na narkotyki. Stanowisku temu towarzyszy brak jakiegokolwiek podziału tych używek w oparciu o spektrum działania, czy też ryzyko powstania uzależnień. Rozróżnienie obszarów podaży i popytu na rynku substancji psychoaktywnych świadczy o liberalizacji stanowiska unijnego i odejściu od kontrowersyjnego brzmienia art. 3 ust. 2 Konwencji Wiedeńskiej z 1988 roku, który to zobowiązuje państwa będące stronami umowy do każdorazowego stosowania sankcji karnych w sytuacji ujawnienia jakichkolwiek narkotyków, i to niezależnie od innych przesłanek.

Warto zaznaczyć, że podstawowe założenia polityki państw Unii Europejskiej $\mathrm{w}$ zakresie zwalczania nielegalnej podaży na narkotyki zawarte są $\mathrm{w}$ założeniach współpracy policyjnej i sądowej w sprawach karnych. Współpraca ta stanowi tzw. III filar Unii Europejskiej i traktują o niej art. 29-42 Traktatu o Unii Europejskiej (Traktat o Unii Europejskiej 1992). Natomiast problematykę związaną z ograniczaniem popytu na środki psychoaktywne UE przenosi do obszaru polityki zdrowotnej, która stanowi już domenę poszczególnych państw członkowskich. Z uwagi na powyższe, ogólne rozwiązania przyjęte w tym zakresie na szczeblu unijnym, zgodnie z zasadą subsydiarności, pełnią jedynie rolę pomocniczą. Tego rodzaju inicjatywy podejmowane przez Radę Unii Europejskiej w celu ograniczenia konsumpcji narkotyków polegają w szczególności na tworzeniu Europejskiej Strategii Zwalczania Narkotyków ${ }^{10}$ oraz Europejskiego Planu Działania w Walce z Narkotykami ${ }^{11}$. Akty tego rodzaju zatwierdzane są natomiast przez Radę Europy. Ostatecznie, w oparciu o przytoczone powyżej dokumenty tworzy się krajowe strategie oraz programy zwalczania narkotyków w poszczególnych państwach członkowskich

Reasumując, stwierdzić należy, że działania podejmowane przez rządy państw członkowskich UE w stosunku do konsumentów narkotyków zmierzają:

- bądź to do zniechęcenia tych osób do zażywania substancji psychoaktywnych poprzez wprowadzenie sankcji karnych;

- lub też skupiają się na stosowaniu szeroko pojętej polityki redukcji szkód (tzw. harm reduction), w ramach której stosuje się leczenie substytucyjne.

Wybór drogi zmierzającej do ograniczenia popytu na substancje psychoaktywne w dużej mierze zależy od polityki narkotykowej konkretnego państwa członkowskiego. Przy czym daje się zauważyć, że w państwach bogatszych przeważają systemy oparte na permisji (nakierowane na leczenie i niwelację szkód zdrowotnych), natomiast kraje mniej zamożne preferują rozwiązania o charakterze mniej lub bardziej prohibicyjnym. Odnosząc się do dwóch wymienionych

$10 \mathrm{http} / /$ europa.eu/legislation_summaries/justice_freedom_security/combating_drugs/ c22569_en.htm [dostęp 29.07.2015].

${ }_{11}$ http://europa.eu/legislation_summaries/justice_freedom_security/combating_drugs/ j10019_en.htm [dostęp 29.07.2015]. 
powyżej systemów, stwierdzić należy, iż obecnie na świecie nie ma już chyba czysto permisywnego czy też czysto prohibicyjnego podejścia do problematyki zwalczania narkotyków i uzależnień, gdyż regułą stały się tzw. modele mieszane.

Kontynuując rozważania nad formą skutecznej reakcji prawnokarnej ze strony organów ścigania związaną z walką z narkomanią oraz niwelacją skali uzależnień, trzeba stwierdzić za A. Gabriele i M. Ostrowską, że możliwe jest tutaj przyjęcie dwóch skrajnych stanowisk, tj.:

1. Uznanie zachowań związanych z używaniem substancji psychoaktywnych bez wyraźnych wskazań lekarskich za przestępstwo w każdym wypadku, w oparciu o wariant:

- rygorystyczny - kiedy penalizacji podlegać będą wszelkie przypadki używania substancji psychoaktywnych;

- permisywny - kiedy zapewnia się w prawie procesowym pewnego rodzaju mechanizmy pozwalające na zaniechanie ścigania osób uzależnionych w pewnych wypadkach, po to aby uniknąć nadmiernej penalizacji;

2. Uznanie za przestępstwo wszelkich zachowań polegających przede wszystkim na nielegalnym obrocie środkami odurzającymi i substancjami psychotropowymi, o ile takie sytuacje mają miejsce poza wyspecjalizowanymi i upoważnionymi do tego podmiotami (np. placówkami służby zdrowia), jak też kryminalizacja pewnych form popytu na narkotyki poprzez sankcjonowanie ich używania, poza przypadkami enumeratywnie wskazanymi w ustawie (Gaberle, Ostrowska 1985, 111-128).

Przyjęcie polityki narkotykowej w tym drugim wariancie oznacza w praktyce przejście do ustawowej i szczegółowej limitacji obszarów związanych z popytem na narkotyki, jeśli chodzi o zakreślenie obszarów penalizacji. W tym przypadku wyłącznie ustawodawca decydował będzie o tym, jakie ilości i jakich narkotyków wolno produkować, czy też posiadać na własny użytek - oczywiście po uprzednim zarejestrowaniu się w odpowiednich placówkach służby zdrowia jako osoba uzależniona. W systemie prohibicji, o którym mowa w pkt. 1, wyróżnione obszary odnoszą się zaś do modelu restrykcyjnego oraz do modelu permisywnego. Permisja w tym przypadku oznacza odejście od represyjnej polityki karania, jeżeli chodzi o popyt na narkotyki, na rzecz polityki bardziej tolerancyjnej. Taka liberalizacja następuje ze względu na osobę konsumenta i może polegać na stworzeniu pewnych mechanizmów w prawie karnym materialnym (np. poprzez wprowadzenie regulacji stanowiących, że sprawca określonego czynu zabronionego związanego z popytem na narkotyki nie będzie podlegać karze), bądź następować poprzez sięgnięcie do pewnego rodzaju instytucji prawa karnego procesowego - jak chociażby instytucja warunkowego umorzenia postępowania karnego.

Kryteriami, które mogą być pomocne przy określeniu prohibicyjności danego systemu prawnego, a tym samym podejścia konkretnego państwa do problemu narkomanii, mogą być takie czynniki, jak: 
- surowość ustawodawstwa karnego danego kraju wobec przyjętego modelu polityki antynarkotykowej;

- szeroka możliwość orzekania środków terapeutycznych w formie przymusowego umieszczenia sprawcy przestępstwa związanego z używaniem narkotyków w zakładzie leczenia odwykowego;

- stosunek zakazu zażywania środków odurzających lub substancji psychotropowych do sankcji przewidzianej za takie naruszenia (Redo 1979).

Reasumując, stwierdzić należy, że podstawowa różnica między permisywnością a represyjnością danego systemu prawnego polega na tym, iż model permisywny kładzie nacisk przede wszystkim na leczenie oraz związaną z tym readaptację osób uzależnionych. Natomiast model stricte represyjny opiera się na dużym zakresie kryminalizacji, przy towarzyszącym temu braku uprzywilejowanego traktowania w stosunku do osób uzależnionych. Takie osoby ponoszą odpowiedzialność karną tak samo, jak ma to miejsce w stosunku do nieuzależnionych sprawców przestępstw narkotykowych (Krajewski 2001, 257).

$\mathrm{Na}$ tle poczynionych uwag należy się odnieść do modelu polityki antynarkotykowej obowiązującej w Rzeczypospolitej Polskiej. Podstawowym aktem prawnym, który reguluje ten obszar zagadnień, jest Ustawa z dnia 29.07.2005 r. o przeciwdziałaniu narkomanii. Wyżej wymieniony dokument jest bez wątpienia jednym z najbardziej restrykcyjnych w całej Europie, jeśli chodzi o penalizację zachowań związanych z konsumenckim zażywaniem bądź posiadaniem wszelkich substancji psychoaktywnych - w tym też tzw. narkotyków miękkich, jak haszysz czy marihuana. Regulacje polskiej ustawy narkotykowej bardzo szeroko sankcjonują wszelkie formy popytu, jak również podaży na narkotyki (Ustawa o przeciwdziałaniu narkomanii... 2005). W obszarze penalizacji znajdują się takie czyny, jak:

- posiadanie narkotyków, ich uprawa i wytwarzanie na własny użytek konsumenta, czy też przystosowywanie przyrządów do nielegalnej konsumpcji narkotyków - po stronie popytu;

- handel, wprowadzanie do obrotu, bądź udzielanie narkotyków innym osobom - po stronie podaży;

Prawdą jest, iż polski ustawodawca przewidział pewne odstępstwa od karalności osób, które popadły w nałóg, takie jak np. warunkowe umorzenie postępowania karnego, umorzenie ze względu na niecelowość orzekania przy niewielkiej ilości narkotyków, czy też zawieszenie postępowania na czas leczenia sprawcy (z możliwością umorzenia), niemniej polski system prawny w odniesieniu do zwalczania przestępczości narkotykowej jest bez wątpienia modelem prohibicyjnym z przewagą elementów represyjnych. Uwzględniając całokształt regulacji prawnych, jakie wynikają ze związania Rzeczypospolitej Polskiej strukturami Unii Europejskiej, takie podejście do problematyki zwalczania przestępczości narkotykowej wydaje się w pełni uzasadnione. Treść międzynarodowych konwencji przyjętych przez Polskę nie pozwala na wydzielenie z obszaru kryminali- 
zacji czynów związanych z posiadaniem tzw. narkotyków miękkich, gdyż byłoby to niezgodne $\mathrm{z}$ celem i ideą ratyfikowania tychże przepisów.

Jeśli wyłączenie poza zakres penalizacji posiadania soft drugs w polskim systemie prawnym nie jest możliwe, to czemu do takiej dekryminalizacji dochodzi na gruncie ustawodawstw Republiki Czeskiej czy też Królestwa Niderlandów? Fakt ten może wzbudzać uzasadnione kontrowersje, zwłaszcza że Czechy i Holandia są stronami tych samych umów międzynarodowych co Polska. Aby odpowiedzieć na tak postawione pytanie, należy przyjrzeć się specyficznym cechom systemów prawnych tychże dwóch państw.

\section{PROBLEMATYKA LEGALIZACJI NARKOTYKÓW MIĘKKICH NA TLE USTAWODAWSTWA KRÓLESTWA NIDERLANDÓW}

Polityka narkotykowa w Królestwie Niderlandów regulowana jest w głównej mierze przez tzw. Ustawę Opiumową z 1976 r. (tzw. Opium Act). Specyfika przyjętych rozwiązań prawnych sprawia, że ustawodawstwo to uznawane jest obecnie za jedno z najmniej restrykcyjnych w całej Europie. Jednakże wnikliwa analiza przepisów wskazanego aktu prawnego pozwala dojść do wniosku, iż przekonanie to nie do końca jest zgodne z prawdą. Wskazać należy, że w Europie istnieją państwa, gdzie pełna dekryminalizacja zachowań polegających na posiadaniu niewielkich ilości narkotyków na wyłączny użytek konsumenta jest faktem. Takimi państwami są chociażby Hiszpania czy Portugalia. Natomiast w Holandii, co warto szczególnie mocno zaakcentować, posiadanie nawet niewielkiej ilości narkotyków objęto sankcją karną.

W związku z powyższym nasuwa się pytanie, skąd zrodziło się przekonanie, że system prohibicji holenderskiej jest bardziej tolerancyjny niż systemy innych państw Unii Europejskiej?

Odwołując się do charakterystycznych cech prohibicji holenderskiej, należy zwrócić uwagę, iż permisywność tego systemu nie wyczerpuje się w depenalizacji, czy też dekryminalizacji wyłącznie popytu na narkotyki. Ustawodawstwo tego kraju przewiduje bowiem możliwość legalizacji pewnych zachowań mieszczących się po stronie podaży na substancje psychoaktywne. Takie podejście wynika z potraktowania zjawisk związanych z niemedycznym zażywaniem substancji psychotropowych czy środków odurzających w kategoriach problemu natury zdrowotnej oraz społecznej, a nie prawnokarnej. Skutkiem takiej polityki jest to, iż sankcje karne stosowane są jedynie w ostateczności i to tylko względem sprawców najpoważniejszych przestępstw narkotykowych. Tymi najcięższymi przestępstwami związanymi z obszarem nielegalnej podaży na narkotyki są czynności sprawcze polegające między innymi na: wprowadzaniu do obrotu, wytwarzaniu, 
wwozie, wywozie bądź też handlu narkotykami. Jednocześnie kryminalizacja powyższych zachowań uzależniona jest od rodzaju używki, a więc od postaci narkotyku. Jest tak, ponieważ holenderski system prawny rozgranicza narkotyki twarde - tzw. hard drugs, od narkotyków miękkich - tzw. soft drugs. W stosunku do narkotyków miękkich prowadzona jest polityka oparta na tolerancji dla tych używek, natomiast w przypadku narkotyków twardych tolerancji przeciwstawiono podejście o typowo represyjnym charakterze. Tym samym holenderska polityka narkotykowa w odniesieniu do hard drugs nie różni się w sposób zasadniczy od modelów, które wypracowano w innych państwach europejskich. Natomiast zwalczanie popytu na narkotyki pozostawione jest w gestii służby zdrowia i innych służb państwowych.

Warto zaznaczyć, że Ustawa opiumowa z 1976 roku dokonuje podziału substancji psychoaktywnych na dwie listy w oparciu o kryterium oceny ryzyka powstania ujemnych skutków dla zdrowia oraz ze względu na możliwość wystąpienia uzależnień w przypadku ich zażywania w celach innych niż medyczne. W ten sposób dokonuje się podziału na narkotyki:

- miękkie, takie jak: marihuana, haszysz, niektóre grzyby halucynogenne oraz

- twarde, takie jak: kokaina, heroina, amfetamina, LSD, czy ekstazy (XTC).

Narkotyki zaliczone do soft drugs niosą ze sobą mniejsze prawdopodobieństwo powstania ujemnych skutków dla zdrowia, jak również uzależniają w mniejszym stopniu niż hard drugs (Krajewski 2001, 287-288).

Charakterystyczną cechą holenderskiego modelu prohibicyjnego jest dopuszczalność funkcjonowania tzw. coffeeshopów, czyli sklepów, gdzie można legalnie nabywać narkotyki miękkie w postaci haszyszu bądź marihuany. Pierwszy taki sklep, tj. herbaciarnia o nazwie Mellow Yellow, powstaje w 1970 roku w Amsterdamie. $Z$ biegiem czasu również w innych lokalach użyteczności publicznej pojawia się możliwość zakupu, a nawet zgodnego z prawem skonsumowania marihuany. Skutkiem tych nowych trendów staje się wykształcenie unikalnego w skali europejskiej systemu prawnego, który niejako toleruje detaliczną sprzedaż narkotyków na własny użytek konsumentów. Na przełomie XX i XXI wieku w Holandii funkcjonuje już około 2000 takich sklepów ${ }^{12}$. Jednakże stały wzrost liczby uzależnień, pojawienie się narkoturystyki, systematyczne zwiększanie się liczby przestępstw, jak również związany z tym sprzeciw władz politycznych ze strony innych państw UE, szybko zmusza rząd Holandii do wprowadzenia pewnych ustępstw na rzecz ograniczenia dostępności do narkotyków. Skutkuje to powstaniem systemu tzw. „wietpasów”, który zaczyna obowiązywać w tym kraju z dniem 1 maja 2012 roku $^{13}$. Te swoistego rodzaju karty klubowe, w teorii zapobiec mają zakupom narkotyków przez obcokrajowców przebywających czasowo na terytorium

\footnotetext{
${ }^{12} \mathrm{http}: / /$ www.amsterdam.info/coffeeshops/mellow_yellow/ [dostęp 30.07.2015].

${ }^{13} \mathrm{http}: / /$ pl.wikipedia.org/wiki/Wietpas [dostęp 31.07.2015].
} 
Królestwa Niderlandów. Zgodnie z nowo przyjętymi regulacjami, ścisłą limitacją objęta zostaje ilość narkotyków zarówno przechowywanych, jak i sprzedawanych w coffeeshopach. Jednocześnie zwiększa się liczba przepisów o charakterze administracyjnym, które zahamować mają powstawanie dalszych sklepów.

W efekcie wprowadzanych zmian, dopuszczalna ilość marihuany możliwa do nabycia przez klienta podczas jednorazowego zakupu w coffeeshopie zmniejsza się z 30 do 5 gramów. Szczególnie oryginalne rozwiązania przyjmuje się w odniesieniu do sposobu zaopatrywania tychże sklepów w marihuanę. Prawo holenderskie wprowadza bowiem dopuszczalny limit używki, jaki można przechowywać w coffeeshopie, wynosi on obecnie $0,5 \mathrm{~kg}$ marihuany na sklep. Zważywszy że posiadanie jakichkolwiek narkotyków, bez względu na motywy tego posiadania oraz rodzaj, jest w prawie holenderskim penalizowane, nasuwa się pytanie, czemu poszczególne sklepy mogą legalnie gromadzić zapasy marihuany w celach dalszej detalicznej (konsumenckiej) odsprzedaży? Tym bardziej że udzielanie jakichkolwiek substancji psychoaktywnych, nie mówiąc już o ich wytwarzaniu, objęto penalizacją $\mathrm{w}$ charakteryzowanym systemie prawnym. Na powyższe pytanie można odpowiedzieć jedynie poprzez odwołanie się do całokształtu rozwiązań przyjętych na gruncie ustawodawstwa karnego Królestwa Niderlandów. Zwłaszcza mechanizmy przyjęte w obszarze procedury karnej pozwalają zrozumieć oryginalność tego modelu prawnego.

W systemie prawa karnego Holandii daje się zauważyć daleko idące odstępstwa od zasady legalizmu procesowego na rzecz zasady oportunizmu ścigania, która wyznacza faktyczny obszar kryminalizacji poszczególnych czynności sprawczych związanych z narkotykami. Oportunizm ścigania polega na wykształceniu określonych priorytetów w polityce narkotykowej tego kraju. W praktyce oznacza to, że na szczeblu odgórnym, a więc państwowym, na drodze tworzenia wytycznych ustala się, które czyny powinny podlegać ściganiu, a co do których można wykazać się dość dużą pobłażliwością. Określanie wytycznych powierzone zostało zespołom prokuratorów działających przy pięciu sądach okręgowych. W ten sposób ustalane są reguły, w oparciu o które kształtuje się lokalna prohibicja narkotykowa. Wytyczne formułowane są na drodze trójstronnych uzgodnień pomiędzy policją, prokuraturą oraz organami samorządu (np. burmistrzami) w danym landzie. Daleko idącą konsekwencją takiego stanu rzecz jest powstanie różnic terytorialnych, zwłaszcza między wielkimi miastami, jak np. Amsterdam, które nastawione są liberalnie, a terenami wiejskimi i małymi miastami, gdzie podejście władz jest bardziej restrykcyjne. Niemniej analizując treść wytycznych, można dojść do wniosku, że największy priorytet przyznają one ściganiu czynów zabronionych związanych z: produkcją, przemytem na wielką skalę, handlem narkotykami „twardymi”, jak również handlem hurtowym i przemytem narkotyków „miękkich”.

Za najniższy priorytet uznano ściganie posiadania marihuany i haszyszu, jak również narkotyków „twardych”, o ile są to niewielkie ilości używki, z przeznaczeniem dla potrzeb własnej konsumpcji (Krajewski 2001, 288-289). 
W ten sposób w prawie holenderskim tolerowane są chociażby:

- posiadanie do 5 gramów narkotyków ,miękkich” bez względu na ich rodzaj (marihuana, haszysz),

- uprawa do 5 roślin konopi indyjskich czy też

- posiadanie do 0,5 grama narkotyków twardych ${ }^{14}$.

Podsumowując, należy podkreślić, iż model prawny przyjęty w Holandii pozwala na odstąpienie od ścigania sprawców drobnych przestępstw narkotykowych, z uwagi na fakt, że wykrywanie takich czynów nie stanowi priorytetu dla organów ścigania. Daleko idąca akceptacja dla marihuany i haszyszu pozwala natomiast na funkcjonowanie tzw. coffeeshopów. Jednakże odstępstwo od zasady legalizmu procesowego na rzecz zasady oportunizmu nie oznacza jeszcze, że posiadanie narkotyków w tym kraju jest legalne i zostało wyjęte spoza zakresu penalizacji. Taka legalizacja jest niemożliwa chociażby ze względu na fakt ratyfikacji przez Królestwo Niderlandów Międzynarodowej Konwencji o zwalczaniu nielegalnego obrotu środkami odurzającymi i substancjami psychotropowymi z 1988 roku, a w szczególności art. 3 ust. 2 wymienionego aktu prawnego. Na koniec warto wskazać, że jedną z podstawowych zalet prohibicji holenderskiej jest położenie dużego nacisku na leczenie substytucyjne, które pozwala na redukowanie szkód zdrowotnych związanych z zażywaniem substancji psychoaktywnych.

\section{ZARYS POLITYKI PROHIBICYJNEJ W ODNIESIENIU DO „NARKOTYKÓW MIĘKKICH” W REPUBLICE CZESKIEJ}

Republika Czeska jest kolejnym krajem, którego system prawny w odniesieniu do kwestii limitacji dostępu do substancji psychoaktywnych wydaje się wskazywać na większą liberalizację przepisów niż ma to miejsce chociażby w Polsce. Prohibicja w tym kraju zakreślona jest poprzez dwojakiego rodzaju regulacje normatywne. Są to:

- po pierwsze, nowy czeski kodeks karny (obowiązujący od 1 stycznia 2010 roku);

- po drugie, dekrety rządowe, które podają definicję rodzajów oraz ilości narkotyków i substancji o działaniu narkotycznym i psychoaktywnym (tzw. NPS).

Podobnie jak ma to miejsce w Królestwie Niderlandów, również i Czechy w powszechnym mniemaniu uważane są zatem za kraj, w którym zalegalizowane zostało posiadanie niewielkich ilości narkotyków przeznaczonych na użytek własny konsumenta. Przekonanie to nie odpowiada jednak rzeczywistości. We wspól-

${ }^{14}$ www.rijksoverheid.nl [dostęp 31.07.2015]. 
nym komunikacie Krajowego Centrum Monitorowania Narkotyków i Narkomanii, Kliniki Addictology Uniwersytetu Karola w Pradze oraz Komendy Głównej Policji, stwierdza się, co następuje:

,[N]ieautoryzowane posiadanie narkotyków na własny użytek jest zawsze nielegalne i karalne $[\ldots]]^{\prime 15}$.

Z uwagi na powyższe, na gruncie przepisów ustawodawstwa czeskiego, karami grzywny 15 tys. koron czeskich ( 2250 zł) objęto czyny wiążące się z posiadaniem narkotyków. Przewidziana sankcja karna oparta jest zarówno na kryterium ilościowym, jak i jakościowym. Jeżeli chodzi o „narkotyki miękkie”, takie jak marihuana czy haszysz, to obowiązujące przepisy penalizują jako wykroczenie posiadanie dość dużych ilości tych używek. Jest to odpowiednio do 15 gramów marihuany oraz do 5 gramów haszyszu ${ }^{16}$.

Stwierdzić należy, że wprowadzenie powyższych limitów wagowych (kryterium ilościowe) nie stanowi nowości w czeskim modelu prohibicyjnym. Jeszcze przed wejściem w życie przepisów ustawy z 2009 roku, podobne ograniczenia przyjmowano na podstawie specjalnych wytycznych policji bądź prokuratury. W ten sposób zmiana, która kształtuje się obecnie w czeskich przepisach karnych, w rzeczywistości sanuje istniejący od dawna stan rzeczy.

Cechą charakterystyczną ustawodawstwa czeskiego jest również to, że szczególnie restrykcyjnie traktuje ono przypadki odnoszące się do sfery podaży narkotyków. Poza tym wprowadza ono dość wyraźne rozróżnienie między narkotykami miękkimi i twardymi, jeśli chodzi o wymiar sankcji karnych. Tytułem przykładu może posłużyć sankcja przewidziana za posiadanie większej niż mała ilości narkotyków miękkich dla celów konsumenckich, której wymiar wynosi do jednego roku pozbawienia wolności. Podczas gdy posiadanie innych substancji psychoaktywnych zagrożone zostało karą do 2 lat pozbawienia wolności. Zauważyć należy, że omawiany system prawny cechuje się dość dużą kazuistyką również jeśli chodzi o sposób formułowania przepisów karnych. Odrębnej penalizacji podlegają bowiem zdarzenia polegające np. na popełnianiu najcięższych przestępstw narkotykowych w warunkach uczestnictwa w zorganizowanej grupie przestępczej (kara od 2 do 10 lat pozbawienia wolności) ${ }^{17}$.

W praktyce oznacza to, że rozwiązania znane w polskim prawie karnym cechują się dość dużą odmiennością w porównaniu do rozwiązań czeskich z uwagi na fakt przewagi rozwiązań o charakterze generalnym - np. przepisy o recydywie, które zaostrzają odpowiedzialność karną.

Jednakże swoistą alternatywą dla stosowania kar izolacyjnych w Republice Czeskiej jest możliwość wydania wyroku skazującego w zawieszeniu przy

\footnotetext{
${ }^{15} \mathrm{http} / / /$ www.drogy-info.cz/ [dostęp 31.07.2015].

${ }^{16} \mathrm{http}: / /$ www.przeglad-tygodnik.pl/pl/artykul/pobuchac-czechach [dostęp 31.07.2015].

${ }^{17} \mathrm{http}: / / w w w . p o l i c i e . c z /$ [dostęp 31.07.2015].
} 
jednoczesnym nałożeniu obowiązku wykonywania prac społecznych i podjęcia leczenia odwykowego. W stosunku do sprawców najbardziej poważnych przestępstw narkotykowych oraz względem młodocianych sprawców takich czynów, sąd może również orzec obowiązek podjęcia przymusowego leczenia odwykowego ${ }^{18}$.

Przedstawiony powyżej zarys czeskiej polityki prohibicyjnej pozwala na sformułowanie wniosku, iż ustawodawstwo tego kraju nie jest aż tak bardzo liberalne, jak można by się tego spodziewać. Sankcje karne przewidziane za większość przestępstw narkotykowych są zróżnicowane i nie mniej restrykcyjne, a często nawet bardziej surowe niż ma to miejsce w polskim systemie prawnym. Liberalizm Republiki Czeskiej w zakresie przyjętej polityki narkotykowej dotyka zatem wyłącznie sfery popytu, a nie podaży narkotyków (w szczególności miękkich). Ustawodawstwo tego kraju akceptuje czynności polegające na posiadaniu bądź też wytwarzaniu (uprawie) substancji psychoaktywnych na niewielką skalę. Jednakże nawet takie czyny nie są relewantne prawnie, gdyż podlegają karze grzywny.

\section{PODSUMOWANIE}

Na tle prezentowanych rozwiązań przyjętych w ustawodawstwach Królestwa Niderlandów oraz Republiki Czeskiej, jeśli chodzi o obszar zwalczania nielegalnego popytu na narkotyki miękkie, polska polityka antynarkotykowa wydaje się niezwykle restrykcyjna. Jednakże po wnikliwym przeanalizowaniu przepisów prawa międzynarodowego, a zwłaszcza licznych regulacji unijnych, okazuje się, że rozwiązania przyjęte w polskim systemie prawnym dość dobrze odzwierciedlają ideę oraz potrzeby wynikające $\mathrm{z}$ ratyfikacji umów, które wiążą Rzeczpospolitą Polską w tym zakresie. Kwestią dyskusyjną jest penalizacja posiadania niewielkiej ilości narkotyków miękkich wyłącznie jako wykroczenia - jak to ma miejsce w Czechach, nie mówiąc już o pełnej depenalizacji takich czynów - co dopuszcza ustawodawstwo holenderskie. Należy zaznaczyć, że zgodnie z art. 62a polskiej ustawy narkotykowej obecnie możliwe jest już umorzenie postępowania karnego (nawet przed jego wszczęciem), jeżeli popełniany czyn polega na posiadaniu niewielkich ilości narkotyków na własny użytek sprawcy. Rozwiązanie to jest przesunięciem granicy penalizacji w stronę większego liberalizmu procesowego i tym samym odstępstwem od bezwzględnej polityki karania za każdy przejaw posiadania narkotyków (bez względu na ich rodzaj oraz ilość). Tym samym na gruncie nowo kształtującej się praktyki w polskim ustawodawstwie antynarkotykowym, legalizm zaczyna ustępować pola tzw. oportunizmowi procesowemu, jako rozwiązaniu zbliżonemu bardziej do modelu holenderskiego. Dalszym krokiem

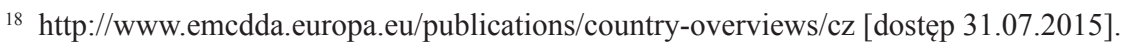


może stać się pełna dekryminalizacja posiadania substancji psychoaktywnych, a zwłaszcza narkotyków miękkich. Jednakże dla ziszczenia się takiego stanu rzeczy konieczna jest daleko idąca zmiana polskiego modelu postępowania karnego i zbudowanie go w oparciu o określone priorytety ( $\mathrm{tj}$. przejście do pełnego oportunizmu procesowego), albo zmiana czy też wręcz wypowiedzenie międzynarodowych porozumień zawartych przez RP w tym zakresie.

Być może dobrym rozwiązaniem byłoby oparcie penalizacji posiadania narkotyków miękkich na modelu czeskim, jako realizującym standardy międzynarodowe, a przy tym uwzględniającym duży margines racjonalności.

\section{BIBLIOGRAFIA}

Gaberle, Andrzej, M. Ostrowska 1985. „Prawo karne wobec narkomanii. Uwagi na tle Ustawy z dnia 31.01.1985 r." Ruch Prawniczy, Ekonomiczny i Socjologiczny.

Krajewski, Krzysztof. 2001. Sens i bezsens prohibicji. Prawo karne wobec narkotyków i narkomanii. Kraków: Zakamycze.

Orzeszkowa, Eliza. 1984. Nad Niemnem. Warszawa: Czytelnik.

Redo, Sławomir. 1979. Narkomania. Aspekty prawne i kryminologiczne. Toruń: Uniwersytet Mikołaja Kopernika.

\section{STRONY INTERNETOWE}

http://www.wiadomosci24.pl/artykul/marihuana_lecznicza_na_nowotwory_i_stwardnienie_rozsiane_bedzie_rewolucja_w_polskiej_medycynie_297737.

http://opioids.com/heroin/heroinhistory.html

http://www.parentscontreladrogue.com/marihuana.htm

http://www.cesar.umd.edu/cesar/drugs/amphetamines.pdf

http://narkotyki.org/narkotyki/lsd/

http://narkotyki.org/narkotyki/kokaina/

http://www.parpa.pl/index.php/analizy-badania-raporty/statystyki

http://www.menshealth.pl/zdrowie/Marihuana-co-w-trawie-piszczy,3638,1

http://www.unic.un.org.pl/incb/index.php

http://europa.eu/legislation_summaries/justice_freedom_security/combating_drugs/c22569_en.htm http://europa.eu/legislation_summaries/justice_freedom_security/combating_drugs/j10019_en.htm http://www.amsterdam.info/coffeeshops/mellow_yellow/

http://pl.wikipedia.org/wiki/Wietpas

www.rijksoverheid.nl

http://www.drogy-info.cz/

http://www.przeglad-tygodnik.pl/pl/artykul/pobuchac-czechach

http://www.policie.cz/

http://www.emcdda.europa.eu/publications/country-overviews/cz 


\title{
AKTY PRAWNE
}

Konwencja Narodów Zjednoczonych o zwalczaniu nielegalnego obrotu środkami odurzającymi i substancjami psychotropowymi, sporządzona w Wiedniu dnia 20 grudnia 1988 r. (Dz. U. 95.15.69).

Jednolita konwencja o środkach odurzających z 1961 roku, sporządzona w Nowym Jorku dnia 30 marca 1961 r. z późn. zm. (Dz. U. 66.45.277).

Konwencja o substancjach psychotropowych z 1971 roku, sporządzona w Wiedniu dnia 21 lutego 1971 r. z późn. zm. (Dz. U. 76.31.180).

Zalecenia Rady 2003/488/WE z dnia 18 czerwca 2003 roku w sprawie zapobiegania i ograniczania szkód zdrowotnych związanych z uzależnieniem od narkotyków (Dz. U. L165 z 03.07.2003).

Komunikat Komisji z dnia 15 grudnia 2005 roku w sprawie zwalczania HIV/AIDS w Unii Europejskiej i państwach z nią sąsiadujących w latach 2006-2009 (COM(2005)0654).

Konwencja Wykonawcza do Układu z Schengen między Rządami Państw Unii Gospodarczej Beneluksu, Republiki Federalnej Niemiec oraz Republiki Francuskiej w sprawie stopniowego znoszenia kontroli na wspólnych granicach (Dz. Urz. UE nr L 239 z 22.09.2000, s. 19).

Układ z Schengen z dnia 14 czerwca 1985 r. (Dz. Urz. UE nr L 239 z dnia 22.09.2000, s. 13).

Ustawa z dnia 29.07.2005 r. o przeciwdziałaniu narkomanii z późn. zm. - tekst jednolity (Dz. U. 2005, Nr 179, poz. 1485).

\section{Marcin Fiedukowicz}

\section{THE ISSUE OF LEGALIZING SOFT DRUGS IN POLAND AGAINST THE LEGAL REGULATIONS ADOPTED IN THE CZECH REPUBLIC AND IN THE NETHERLANDS}

\begin{abstract}
The aim of this publication is to bring closer legal regulations referring to issues of legalization and availability of soft drugs in Poland. Basing on regulations of the international law as well as on the most important acts of the intra-Community law fundamental reasons are indicated for which depenalization of behaviours such as the possession or production of the so-called soft drugs is not at present possible. Comparing regulations of penalties of the Polish drug act allows setting necessary guidelines for changes to the Polish prohibition model. In this context the author is presenting fundamental assumptions of the anti-drug policies adopted in the Netherlands and Czech Republic as the states with a less restrictive (radical) approach to the issue of drug possession. The considerations undertaken allow finally formulating an answer to a question: Is it reasonable to legalize at least the so-called 'soft drugs' or should the binding legal regulations be maintained without changes, punishing always and for every manifestation of drug possession and irrespectively of a type of drugs?
\end{abstract}

Keywords: drugs, criminalization, decriminalization, drugs possession, soft drugs, legalization, prohibition. 